\title{
Amblyomma hebraeum is the predominant tick species on goats in the Mnisi Community Area of Mpumalanga Province South Africa and is co-infected with Ehrlichia ruminantium and Rickettsia africae
}

Frans Jongejan ${ }^{1 *}$, Laura Berger², Suzanne Busser ${ }^{2,3}$, Iris Deetman², Manon Jochems ${ }^{2}$, Tiffany Leenders², Barry de Sitter ${ }^{2,4}$, Francine van der Steen ${ }^{2}$, Jeanette Wentzel ${ }^{5}$ and Hein Stoltsz ${ }^{1}$

\begin{abstract}
Background: In sub-Saharan Africa, Amblyomma ticks are vectors of heartwater disease in domestic ruminants, caused by the rickettsial pathogen Ehrlichia ruminantium. Immature tick stages often bite humans, whereby they act as vectors of tick-bite fever caused by Rickettsia africae. Moreover, Amblyomma ticks cause damage to livestock due to their feeding behaviour. In South Africa, we studied the abundance of Amblyomma hebraeum ticks on goats of emerging farmers in Mpumalanga Province. A selected number of $A$. hebraeum nymphs and adult ticks was tested for co-infection with E. ruminantium and $R$. africae.

Methods: A total of 630 indigenous goats, belonging to farmers in the Mnisi Community area, were examined for ticks in 2013 and 2014. All ticks were identified, and a selected number was tested by PCR with reverse line blot hybridisation.

Results: In total, 13,132 ticks were collected from goats distributed over 17 different households. Amblyomma hebraeum was the predominant species, followed by R. microplus. Rhipicephalus appendiculatus, R. simus and R. zambeziensis were also identified. Amblyomma hebraeum was present throughout the year, with peak activity of adults in summer (November) and nymphs in winter (July). The ratio between adults and nymphs ranged from 1:2.7 in summer to 1:55.1 in winter. The mean prevalence of infection for E. ruminantium by PCR/RLB in adult ticks was 17.4\% (31/178), whereas $15.7 \%$ (28/178) were infected with $R$. africae. In pooled nymphs, $28.4 \%$ were infected with E. ruminantium and $38.8 \%$ carried $R$. africae infection. Co-infections of E. ruminantium and $R$. africae in adult and pooled nymphal ticks were $3.9 \%(7 / 178)$ and $10 \%(14.9)$, respectively. Lameness of goats due to predilection of ticks for the interdigital space of their feet was observed in $89 \%$ of the households.
\end{abstract}

Conclusions: Goats act as important alternative hosts for cattle ticks, which underscored the necessity to include goats in control programs. It is suggested to use acaricide-impregnated leg-bands as a sustainable method to kill ticks and prevent lameness in goats. The challenge of goats by considerable numbers of E. ruminantium-infected ticks is

\footnotetext{
*Correspondence: Frans.Jongejan@gmail.com

${ }^{1}$ Vectors and Vector-borne Diseases Research Programme, Department

of Veterinary Tropical Diseases, Faculty of Veterinary Science, University

of Pretoria, Private Bag X04, Onderstepoort 0110, Republic of South Africa

Full list of author information is available at the end of the article
}

(c) The Author(s) 2020. This article is licensed under a Creative Commons Attribution 4.0 International License, which permits use, sharing, adaptation, distribution and reproduction in any medium or format, as long as you give appropriate credit to the original author(s) and the source, provide a link to the Creative Commons licence, and indicate if changes were made. The images or other third party material in this article are included in the article's Creative Commons licence, unless indicated otherwise in a credit line to the material. If material is not included in the article's Creative Commons licence and your intended use is not permitted by statutory regulation or exceeds the permitted use, you will need to obtain permission directly from the copyright holder. To view a copy of this licence, visit http://creativecommons.org/licenses/by/4.0/. The Creative Commons Public Domain Dedication waiver (http://creativecommons.org/publicdomain/zero/1.0/) applies to the data made available in this article, unless otherwise stated in a credit line to the data. 
a major obstacle for upgrading the indigenous goat breeds. Humans may be at risk to contract tick-bite fever in this area.

Keywords: Amblyomma hebraeum ticks, South Africa, Ehrlichia ruminantium, Heartwater, Rickettsia africae, Tick bite fever

\section{Background}

Ticks and tick-borne diseases constitute a major cause of economic loss to the livestock sector, in particular with respect to the production of cattle and small ruminants in tropical and sub-tropical areas [1]. Ticks are also of great importance to companion animals, livestock and humans due to their capacity to transmit a broad range of bacterial, protozoan and viral pathogens [2, 3]. In subSaharan Africa, ixodid ticks, in particular Amblyomma species, are of significant concern regarding their ability to transmit Ehrlichia ruminantium. This rickettsial pathogen belongs to the family Anaplasmataceae and is widely distributed throughout sub-Saharan Africa, where it causes heartwater disease in cattle and in small ruminants [4]. Another rickettsial pathogen also transmitted by Amblyomma ticks is Rickettsia africae, which is the cause of African tick-bite fever in humans [5]. Tickbite fever is a well-known disease affecting travellers to sub-Saharan Africa and characterised by fever, multiple eschars and maculopapular skin rashes, but is usually resolved after doxycycline therapy [6-8].

In southern Africa, indigenous goats play an important economic and cultural role in the livelihoods of the rural farming communities [9]. However, cattle create more value and status in these communities and are therefore usually better cared for than goats. Nevertheless, one needs to keep in mind that goat production efficiency cannot be measured in saleable livestock numbers only, since raising goats is considered an insurance against emergencies by these farmers. Farmers' perception of mortality among young goats under communal farming conditions in South Africa has been surveyed, whereby ectoparasites (predominantly ticks) scored high and were perceived a major cause of mortality [10].

Amblyomma hebraeum, also known as the South African bont tick, is a notorious tick infesting cattle, sheep and goats as well as a range of wildlife species; it is also the local vector of heartwater disease. Amblyomma hebraeum is exclusively a southern African tick and occurs in the coastal regions of the Eastern Cape and KwaZulu-Natal provinces in South Africa as well as in southern Mozambique. Its distribution extends inland through Swaziland, the Mpumalanga, Limpopo and North West provinces of South Africa into eastern Botswana to south-western Zimbabwe [11, 12]. Tick infestation on cattle can lead to the loss of udder quarters, whereas scrotal tick damage has recently been linked to infertility in communal bulls in the North West Province in South Africa [13]. In goats, skin lesions, in particular in the inter-digital space (a predilection site for the ticks) are prone to secondary infections and often result in lameness. The association between foot abscesses in goats and the relationship with adult $A$. hebraeum ticks has already been known for more than 30 years [14].

At a farmers' day organised in the Mnisi Community area, farmers confirmed that they are often confronted with lameness of their goats due to tick infestation. Moreover, owners indicated that they have to cope with losses when goats die suddenly or after displaying leg-pedalling movements prior to death. The latter is an indication that some of their goats acquire a fatal $E$. ruminantium infection transmitted by Amblyomma ticks and succumb to heartwater disease, although a definitive diagnosis is usually not made.

Besides ticks of the genus Amblyomma, insight into the overall species composition and distribution of ticks infesting goats is relevant. Ticks found on goats may play a role in the epidemiology of cattle diseases and may carry zoonotic pathogens [15]. It has been reported that tick species other than $A$. hebraeum, commonly infesting goats in the Eastern Cape Province and in Maputo Province, were Rhipicephalus microplus, $R$. appendiculatus and $R$. evertsi $[11,15]$. One tick of particular importance is the Asian blue tick, $R$. microplus. This tick primarily uses cattle as hosts and is usually only found on other animals provided infested cattle are present at the same location. Finding R. microplus on goats therefore indicates that this species is in the process of adapting to goats [15]. On cattle, in the Eastern Cape Province and Maputo Province, displacement of the indigenous tick $R$. decoloratus by the introduced species $R$. microplus has already taken place [16].

In the Mnisi Community area, situated in Mpumalanga Province in close proximity to the southern part of the Kruger National Park, surveys of ticks on small ruminants have not been carried out. Also, displacement of $R$. decoloratus by $R$. microplus may have occurred in this area, but this needs to be confirmed. As the study area borders on wildlife areas, and R. microplus is known to feed on wildlife hosts, the presence or absence of this species on goats may be of significance.

In this context, the aim of this study was to investigate the relative abundance of ticks and their impact 
on indigenous goats owned by emerging farmers in the Mnisi Community area as a basis for a sound intervention strategy to reduce the direct and indirect damage caused by ticks. Information on the species composition of ticks infesting goats will provide a better understanding of the potential transmission of tick-borne pathogens affecting local livestock and the possible risks for humans to acquire zoonotic tick-borne diseases.

\section{Methods}

\section{Study area}

The study area encompassed households in 17 villages in the area of Mnisi, province of Mpumalanga, South Africa (Fig. 1). This area covers about 29,500 hectares and is situated in the northeastern corner of the Bushbuckridge Municipal Area within a typical savannah ecosystem. It is surrounded by the adjacent Andover and Manyeleti provincial game reserves as well as by the Kruger National Park (Fig. 1). The Mnisi community consists of over 40,000 people, divided over an estimated 8555 households, of which 917 different goat farmers own a total of approximately 6000 goats. The area is part of the Mnisi Community Programme, an initiative by the University of Pretoria and the Mnisi Traditional Authority. Diptanks (numbers 1-16) are operational for cattle in or near all 17 villages in the Mnisi area at no cost to the farmers (Fig. 1). Seventeen households located in or near the villages were included in the study.

\section{Study design}

In both collections conducted in 2013, the number of goats varied considerably, whereas the collections in 2014 could be standardised to 10 animals per household. Goats were randomly selected in the morning in their kraals prior to going out for grazing. In total, 630 goats were examined for ticks by conducting whole body collections. Ticks were stored in collection tubes containing $70 \%$ ethanol. Each tube was labelled with the date, household and predilection site on the goat. The adult ticks were identified to the species level, whereas the nymphs were separated according to the genus under a stereoscopic microscope using standard taxonomic keys. Larvae from each collection tube were examined under the microscope to confirm the presence of Amblyomma. The mean number of $A$. hebraeum ticks per goat collected in each sampling period was statistically analysed by using a two-tailed, Mann-Whitney U-test.

\section{DNA extraction}

Amblyomma hebraeum ticks were placed in sterile $2 \mathrm{ml}$ microcentrifuge tubes containing $180 \mu \mathrm{l}$ of a lysis buffer (GeneJet genomic DNA purification kit, Thermo Fisher Scientific, Landsmeer, the Netherlands) and were frozen at $-20{ }^{\circ} \mathrm{C}$. Adult ticks were tested individually, nymphs in pools of ten ticks. Thereafter, metal beads $(5 \mathrm{~mm}$ in diameter) were added to the frozen samples, which were disrupted in a TissueLyser (Qiagen Benelux BV, Venlo, the Netherlands) for $3 \mathrm{~min}$ at $50 \mathrm{~Hz}$. The DNA was extracted from the triturated samples by using a GeneJet genomic DNA purification kit (Thermo Fisher Scientific, Landsmeer, the Netherlands) according to the instructions of the manufacturer. Extracted DNA was eluted in $150 \mu \mathrm{l}$ elution buffer and used directly or stored at -20 ${ }^{\circ} \mathrm{C}$. After extraction, DNA was PCR amplified and tested by reverse line blot hybridisation (RLB).

\section{PCR}

For Anaplasma/Ehrlichia and Rickettsia PCR, the primer pair Ehr-F2 (5'-AGA GTT TGA TCC TGG CTC AG-3') and Ehr-R2 (5'-biotin-GAG TTT GCC GGG ACT TYT TCT-3') was used to amplify the V1 variable region from the $16 S$ rRNA gene [17]. The length of the PCR amplicon was 460-500 bp. Each PCR was performed in a volume of $20 \mu \mathrm{l}$, containing $10 \mu \mathrm{l}$ of $2 \times$ Phusion Hot Start High Fidelity Master Mix (Thermo Fisher Scientific), $0.5 \mu \mathrm{M}$ of each primer and $2 \mu \mathrm{l}$ of extracted genomic DNA; the remaining volume was double-distilled water. The PCR primers were purchased from Life Technologies Europe BV, Bleiswijk, the Netherlands. As positive controls, genomic DNA from Ehrlichia canis was used. Distilled water was used as negative control.

\section{Reverse line blot (RLB) hybridisation}

Reverse line blot (RLB) hybridisation has the advantage of enabling the analysis of multiple samples against multiple probes simultaneously and is used to differentiate Anaplasma and Ehrlichia species [17]. Probes for the differentiation of Rickettsia species were also added to the membrane. Oligonucleotide probes containing an N-terminal $\mathrm{N}$-(trifluoracetamidohexyl-cyanoethyl-N,N-diisopropyl phosphoramidite [TFA])-C6 amino linker were synthesised by Thermo Fisher Scientific. Specific probes targeted eight Ehrlichia/Anaplasma species; in addition to one catch-all probe for Ehrlichia/Anaplasma, specific probes to differentiate $E$. ruminantium from a range of related species were included. These were $A$. centrale, A. marginale, A. phagocytophilum, A. bovis, A. platys, E. canis and E. chaffeensis. Finally, R. conorii, R. helvetica, $R$. africae and $R$. raoultii, as well as a catch-all probe for Rickettsia detection, completed the membrane [18].

The RLB hybridisation was conducted as described previously [19]. Briefly, Biodyne C membranes were activated using $16 \%$ (wt/wv) 1-ethyl-3-(3-dimethylamino-propyl) carbodiimide (EDAC) (Carl Roth $\mathrm{GmbH}$, Karlsruhe, Germany) for 10 min, after which the oligonucleotide probes were linked covalently to the membrane 


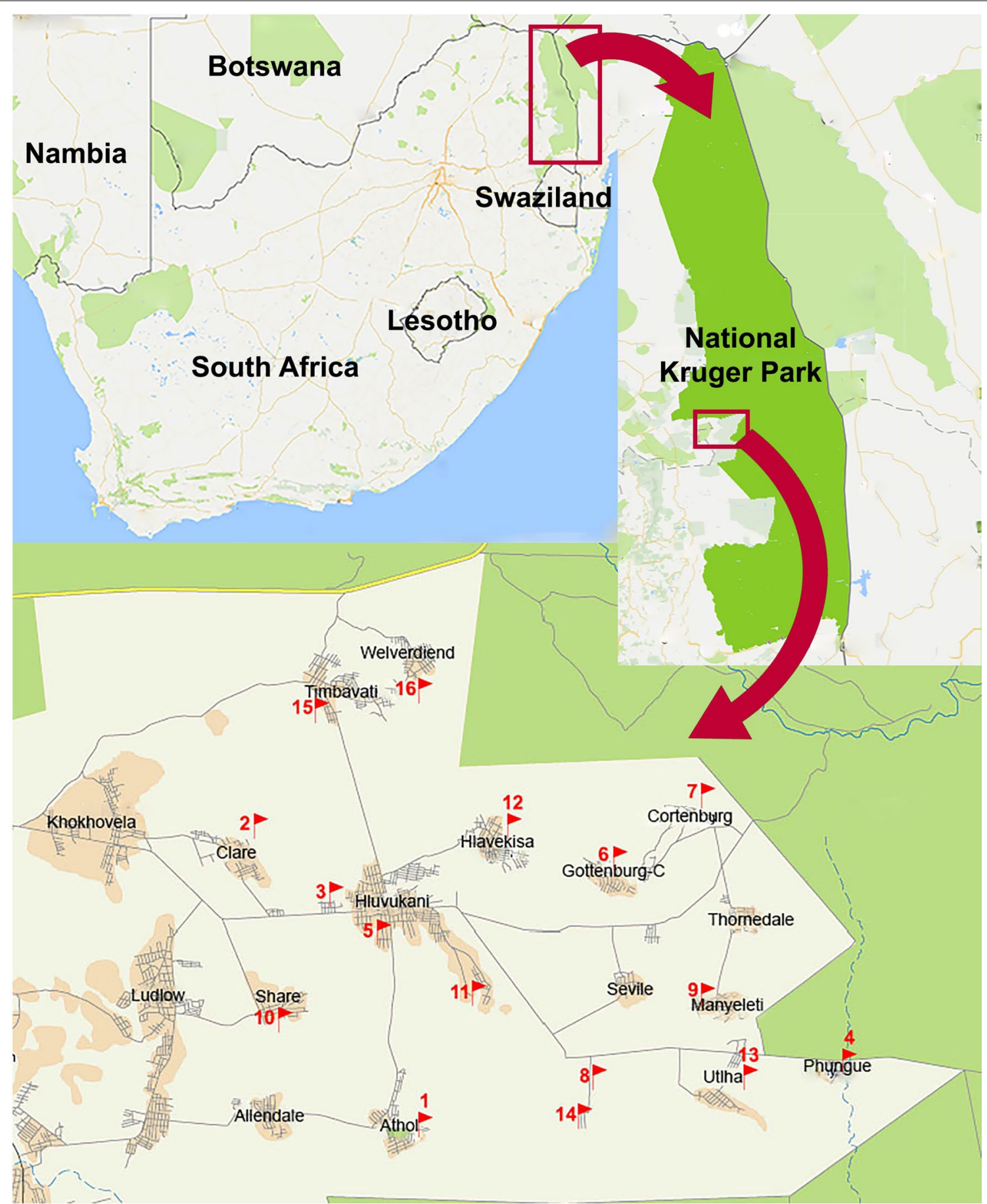

Fig. 1 Geographical location of the Mnisi Community study area in Mpumalanga Province of South Africa

in $0.5 \mathrm{M} \mathrm{NaHCO}_{3}$, using a mini-blotter. Thereafter, the membrane was inactivated in $100 \mathrm{mM} \mathrm{NaOH}$, washed in $2 \times \mathrm{SSPE} / 0.1 \%$ SDS at $60{ }^{\circ} \mathrm{C}$ and subsequently stored in $20 \mathrm{mM}$ EDTA of $\mathrm{pH}$ 8.0. In each RBL assay, $10 \mu \mathrm{l}$ of PCR product were added to $150 \mu \mathrm{l}$ of $2 \times$ SSPE/0.1\% SDS after denaturing for $10 \mathrm{~min}$ at $100{ }^{\circ} \mathrm{C}$, followed by immediate cooling down on ice. Denatured PCR products were than hybridised to the Biodyne $\mathrm{C}$ membrane for $60 \mathrm{~min}$ at $42{ }^{\circ} \mathrm{C}$. Subsequently, membranes were washed twice in $2 \times \mathrm{SSPE} / 0.5 \% \mathrm{SDS}$ for $10 \mathrm{~min}$ at $50{ }^{\circ} \mathrm{C}$, incubated at 42 
${ }^{\circ} \mathrm{C}$ for $30 \mathrm{~min}$ in $2 \times \mathrm{SSPE} / 0.5 \%$ SDS with $5 \mu \mathrm{l}$ of streptavidin-POD conjugate (Roche Diagnostics, Mannheim, Germany), washed twice in $2 \times \mathrm{SSPE} / 0.5 \%$ SDS at $42{ }^{\circ} \mathrm{C}$ for $10 \mathrm{~min}$ and finally washed in $2 \times$ SSPE at room temperature for $5 \mathrm{~min}$. Detection was carried out via chemiluminescence, using Amersham ECL detection reagents (Roche Diagnostics, Mannheim, Germany).

\section{Results}

\section{Tick collections}

The tick species identified and the number of ticks collected from the goats are summarised in Tables 1, 2, 3 and 4. In total, 13,132 ticks were collected from goats distributed over 17 different households in the study area in Mpumalanga Province (Fig. 1). Five adult tick species were identified: $A$. hebraeum, $R$. microplus, $R$. appendiculatus, $R$. zambeziensis and $R$. simus. Amblyomma hebraeum was the predominant adult tick species, followed by $R$. microplus (Tables 1, 2, 3 and 4). The relative proportion of adult Amblyomma ticks versus the other tick species was $66.2 \%$. A total of 4268 larvae was also collected from the goats. Adults as well as nymphal $A$. hebraeum ticks preferred to attach inside the interdigital space of the feet of goats, often leading to secondary infections and lameness, which was observed in $89 \%$ of the households (Fig. 2).
In 2013, 3387 ticks were collected from 117 goats in July and a further 2732 ticks from 184 goats in November (Tables 1, 2). In 2014, 2884 ticks were collected from 169 goats in March, and 4129 ticks were removed from 160 goats in July (Tables 3,4 ). Large numbers of $A$. hebraeum nymphs were present all year round (Tables 1, 2, 3 and 4). Nymphs $(n=7537)$ were either $A$. hebraeum or belonged to the genus Rhipicephalus, which were not further identified to the species level. The relative proportion of nymphal Amblyomma ticks versus other tick species was 93.5\%. The mean number of adult $A$. hebraeum ranged between 0.2 and 2.8 ticks per goat, whereas nymphs ranged between 7.5 and 19.7 ticks per goat (Table 5). There was a significant difference in the mean burden of ticks per goat between the four collections (Table 5). The ratio between adults and nymphs ranged from 1:2.7 in summer to 1:55.1 in winter (Table 5).

\section{Pathogen detection}

The reverse line blot results with adult $A$. hebraeum ticks collected in November 2013 are shown in Fig. 3. Adult ticks were positive for either E. ruminantium or $R$. africae or both, whereas none of the other rickettsial pathogens were present. The RLB results for nymphs collected in the same month are shown in Fig. 4. They were also clearly positive for either E. ruminantium or $R$. africae

Table 1 Species composition and total number of ticks collected from goats in the Mnisi Community Area of Mpumalanga Province, South Africa, in July 2013

\begin{tabular}{|c|c|c|c|c|c|c|c|c|c|c|}
\hline \multirow[t]{2}{*}{ Village } & \multirow[t]{2}{*}{ No. of goats } & \multicolumn{5}{|c|}{ Adults } & \multicolumn{2}{|c|}{ Nymphs } & \multirow[t]{2}{*}{ Larvae } & \multirow[t]{2}{*}{ Total } \\
\hline & & $\mathrm{AH}$ & $\mathrm{RM}$ & RA & RS & $\mathrm{RZ}$ & A & $R$ & & \\
\hline Athol & 11 & & 3 & & & & 21 & 2 & 236 & 262 \\
\hline Clare $(\mathrm{H} 1)$ & 3 & 1 & 16 & 1 & & & 21 & & 60 & 99 \\
\hline Clare $(\mathrm{H} 2)$ & 3 & & 1 & & & & 32 & & 77 & 110 \\
\hline Cortenburg & 14 & & & & & & 110 & 5 & 85 & 200 \\
\hline Gottenburg-C & 2 & & & & & & 14 & & 2 & 16 \\
\hline Hlavakisa & 8 & 9 & & & & & 132 & 3 & 62 & 206 \\
\hline Hluvukani (H1) & 7 & 2 & 4 & & & & 70 & & 92 & 168 \\
\hline Hluvukani (H2) & 14 & 5 & 1 & & & 1 & 50 & 22 & 13 & 92 \\
\hline Ludlow & 8 & & 11 & & & & 38 & & 55 & 104 \\
\hline Phungue & 1 & 1 & 12 & & & & 92 & 2 & 240 & 347 \\
\hline Share & 11 & & 2 & & & & 35 & & 77 & 114 \\
\hline Seville & 3 & & 1 & & & & 48 & 11 & 0 & 60 \\
\hline Thorndale & 4 & 1 & 1 & & & & 36 & & 38 & 76 \\
\hline Timbavati & 14 & 1 & 71 & & 1 & 1 & 90 & 23 & 108 & 295 \\
\hline Utha $(\mathrm{H} 1)$ & 4 & 3 & 30 & & & & 327 & & 650 & 1010 \\
\hline Utha $(\mathrm{H} 2)$ & 5 & & 2 & & & & 41 & 5 & 31 & 79 \\
\hline Welverdiend & 5 & & 6 & & & & 37 & & 106 & 149 \\
\hline Total & 117 & 23 & 161 & 1 & 1 & 2 & 1194 & 73 & 1932 & 3387 \\
\hline
\end{tabular}

Abbreviations: $\mathrm{H1}$, Household 1; H2, Household 2; AH, Amblyomma hebraeum; RM, Rhipicephalus microplus; RA, Rhipicephalus appendiculatus; RS, Rhipicephalus sinus; RZ, Rhipicephalus zambeziensis; A, Amblyomma; R, Rhipicephalus 
Table 2 Species composition and total number of ticks collected from goats in the Mnisi Community Area of Mpumalanga Province, South Africa, in November 2013

\begin{tabular}{|c|c|c|c|c|c|c|c|}
\hline \multirow[t]{2}{*}{ Village } & \multirow[t]{2}{*}{ No. of goats } & \multicolumn{2}{|c|}{ Adults } & \multicolumn{2}{|c|}{ Nymphs } & \multirow[t]{2}{*}{ Larvae } & \multirow[t]{2}{*}{ Total } \\
\hline & & $\mathrm{AH}$ & RM & A & $\mathrm{R}$ & & \\
\hline Athol & 10 & 13 & 3 & 102 & 2 & 48 & 168 \\
\hline Clare $(\mathrm{H} 1)$ & 7 & 32 & & 16 & & 17 & 65 \\
\hline Clare $(\mathrm{H} 2)$ & 10 & 34 & & 51 & & 5 & 90 \\
\hline Cortenburg & 9 & 40 & & 58 & 10 & 96 & 204 \\
\hline Gottenburg-C & 19 & 67 & 7 & 88 & & 41 & 203 \\
\hline Hlavekisa & 15 & 71 & & 304 & & 85 & 460 \\
\hline Hluvukani (H1) & 10 & 15 & & 102 & & 46 & 163 \\
\hline Hluvukani (H2) & 14 & 17 & 4 & 20 & 3 & 9 & 53 \\
\hline Ludlow & 6 & 6 & 11 & 114 & 2 & 24 & 157 \\
\hline Phungue & 7 & 9 & & 30 & & 3 & 42 \\
\hline Share & 5 & 48 & 4 & 17 & & 3 & 72 \\
\hline Seville (H1) & 13 & 16 & 4 & 62 & & 66 & 148 \\
\hline Seville $(\mathrm{H} 2)$ & 10 & 45 & & 97 & & 68 & 210 \\
\hline Thorndale & 13 & 37 & 1 & 156 & 1 & 97 & 292 \\
\hline Timbavati & 9 & 22 & 1 & 67 & 1 & 10 & 101 \\
\hline Utha $(\mathrm{H} 1)$ & 7 & 33 & & 50 & & 46 & 129 \\
\hline Utha $(\mathrm{H} 2)$ & 7 & 9 & & 68 & & 28 & 105 \\
\hline Welverdiend & 13 & 8 & & 28 & & 34 & 70 \\
\hline Total & 184 & 522 & 35 & 1430 & 19 & 726 & 2732 \\
\hline
\end{tabular}

Abbreviations: $\mathrm{H} 1$, Household 1; H2, Household 2; AH, Amblyomma hebraeum; RM, Rhipicephalus microplus; A, Amblyomma; R, Rhipicephalus

Table 3 Species composition and total number of ticks collected from goats in the Mnisi Community Area of Mpumalanga Province, South Africa, in March 2014

\begin{tabular}{|c|c|c|c|c|c|c|c|c|}
\hline \multirow[t]{2}{*}{ Village } & \multirow[t]{2}{*}{ No. of goats } & \multicolumn{3}{|c|}{ Adults } & \multicolumn{2}{|c|}{ Nymphs } & \multirow[t]{2}{*}{ Larvae } & \multirow[t]{2}{*}{ Total } \\
\hline & & $\mathrm{AH}$ & RM & RA & A & $\mathrm{R}$ & & \\
\hline Athol & 10 & 16 & 117 & 1 & 182 & 152 & 526 & 994 \\
\hline Clare $(\mathrm{H} 1)$ & 10 & 11 & 9 & 3 & 51 & 6 & 12 & 92 \\
\hline Clare $\left(\mathrm{H}_{2}\right)$ & 10 & 13 & 9 & & 40 & 13 & 1 & 76 \\
\hline Cortenburg & 10 & 5 & 1 & & 55 & & 3 & 64 \\
\hline Gottenburg-C & 10 & 29 & 1 & & 62 & 1 & 10 & 103 \\
\hline Hlavekisa & 10 & 1 & & & 42 & 3 & 21 & 67 \\
\hline Hluvukani (H1) & 10 & 1 & & 3 & 254 & 2 & 58 & 318 \\
\hline Hluvukani (H2) & 10 & 17 & 30 & & 39 & 61 & 54 & 201 \\
\hline Ludlow & 10 & 2 & 5 & 2 & 130 & 9 & 97 & 245 \\
\hline Phungue & 10 & 19 & 4 & & 49 & & 1 & 73 \\
\hline Share & 9 & 25 & 14 & 2 & 59 & 26 & 4 & 130 \\
\hline Seville & 10 & 14 & 4 & 5 & 53 & 9 & 0 & 85 \\
\hline Thorndale & 10 & 2 & & & 77 & & 8 & 87 \\
\hline Timbavati & 10 & 2 & 2 & 2 & 42 & 5 & 6 & 59 \\
\hline Utha $(\mathrm{H} 1)$ & 10 & 60 & 1 & 2 & 37 & & & 100 \\
\hline Utha $(\mathrm{H} 2)$ & 10 & 1 & 5 & 1 & 78 & 5 & 71 & 161 \\
\hline Welverdiend & 10 & 1 & & & 22 & & 6 & 29 \\
\hline Total & 169 & 219 & 202 & 21 & 1272 & 292 & 878 & 2884 \\
\hline
\end{tabular}


Table 4 Species composition and total number of ticks collected from goats in the Mnisi Community Area of Mpumalanga Province, South Africa, in July 2014

\begin{tabular}{|c|c|c|c|c|c|c|c|c|}
\hline \multirow[t]{2}{*}{ Village } & \multirow[t]{2}{*}{ No. of goats } & \multicolumn{3}{|c|}{ Adults } & \multicolumn{2}{|c|}{ Nymphs } & \multirow[t]{2}{*}{ Larvae } & \multirow[t]{2}{*}{ Total } \\
\hline & & $\mathrm{AH}$ & $\mathrm{RM}$ & RA & A & $\mathrm{R}$ & & \\
\hline Athol & 10 & & & & 248 & 7 & 81 & 336 \\
\hline Clare $(\mathrm{H} 1)$ & 10 & 25 & 5 & & 267 & 11 & 50 & 358 \\
\hline Clare $(\mathrm{H} 2)$ & 10 & 1 & 1 & & 67 & & 17 & 86 \\
\hline Cortenburg & 10 & 2 & & & 221 & 1 & 31 & 255 \\
\hline Gottenburg-C & 10 & 3 & 2 & & 336 & 10 & 60 & 411 \\
\hline Hlavekisa & 10 & 2 & 3 & & 378 & 4 & 111 & 498 \\
\hline Hluvukani (H1) & 10 & 2 & & & 143 & & 5 & 150 \\
\hline Hluvukani (H2) & 10 & & & & 72 & & 8 & 80 \\
\hline Ludlow & 10 & 5 & & & 274 & 47 & 60 & 386 \\
\hline Phungue & 10 & 1 & & & 150 & & 127 & 278 \\
\hline Share & 10 & 50 & 12 & & 128 & 4 & 1 & 195 \\
\hline Seville & 10 & & & & 173 & & 41 & 214 \\
\hline Thorndale & 10 & 11 & & & 247 & & 21 & 279 \\
\hline Timbavati & 10 & 7 & 2 & 1 & 134 & 26 & 70 & 240 \\
\hline Utah & 10 & 3 & & & 123 & & 33 & 159 \\
\hline Welverdiend & 10 & 2 & & & 186 & & 16 & 204 \\
\hline Total & 160 & 114 & 25 & 1 & 3147 & 110 & 732 & 4129 \\
\hline
\end{tabular}

Abbreviations: $\mathrm{H} 1$, Household 1; H2, Household 2; AH, Amblyomma hebraeum; RM, Rhipicephalus microplus; RA, Rhipicephalus appendiculatus; A, Amblyomma; R, Rhipicephalus

or both, whereas one $R$. africae positive tick was also positive for A. centrale (Fig. 4). The mean prevalence of infection for E. ruminantium detected by PCR/RLB in adult $A$. hebraeum ticks was $17.4 \%$ (31/178), whereas $15.7 \%$ (28/178) were infected with $R$. africae (Table 6). In pooled nymphs, $28.4 \%$ were infected with E. ruminantium, and $38.8 \%$ carried an infection of $R$. africae. Coinfections of E. ruminantium $+R$. africae in adult and pooled nymphal ticks were $3.9 \%(7 / 178)$ and $10 \%(10 / 67)$, respectively (Table 6).

\section{Discussion}

The rationale for conducting this study was to collect important baseline information concerning ticks infesting goats and possible zoonotic risks as a basis for subsequent sustainable intervention strategies. The study, conducted in the Mnisi Community Area of Mpumalanga Province in South Africa, demonstrates that ticks affected indigenous goats owned by emerging farmers and were also a potential risk of transmitting zoonotic diseases to humans. More than 13,000 ticks were collected from goats distributed over 17 different households, with $A$. hebraeum being the predominant species collected, followed by $R$. microplus. Small numbers of $R$. appendiculatus, $R$. simus and $R$. zambeziensis were also identified (Tables 1, 2, 3 and 4). With only one species of Amblyomma found here, it can be assumed that all Amblyomma nymphs also belonged to A. hebraeum. However, this cannot be assumed for Rhipicephalus nymphs, since there were adult ticks of at least four different Rhipicephalus species identified. As far as larvae are concerned, these consisted of Amblyomma as well as Rhipicephalus. Although not individually identified, the presence of Amblyomma larvae was confirmed in each of the four collections. Thus, all three developmental stages of $A$. hebraeum were collected at each sampling, whereby the ratio between adults and nymphs ranged from 1:2.7 in summer to 1:55.1 in winter (Table 5). Although a considerable number of goats $(n=630)$ was sampled, the number of collections was limited to only four, which implies that the protocol was not designed to reveal the entire seasonal dynamics. Instead, the study was designed to determine the species distribution and abundance of ticks on goats at different times of the year as a baseline for subsequent intervention strategies.

The seasonal occurrence of $A$. hebraeum has been studied before and appears to be climate-dependent and to vary throughout its distributional range of the tick. The species has a three-host life-cycle, with larvae, nymphs and adults feeding on separate hosts. In general, adults tend to be most numerous during the warm, wet summer months, larvae during the colder, dry, late autumn and winter months, and nymphs during the winter and spring months. Our results confirm that varying numbers of 


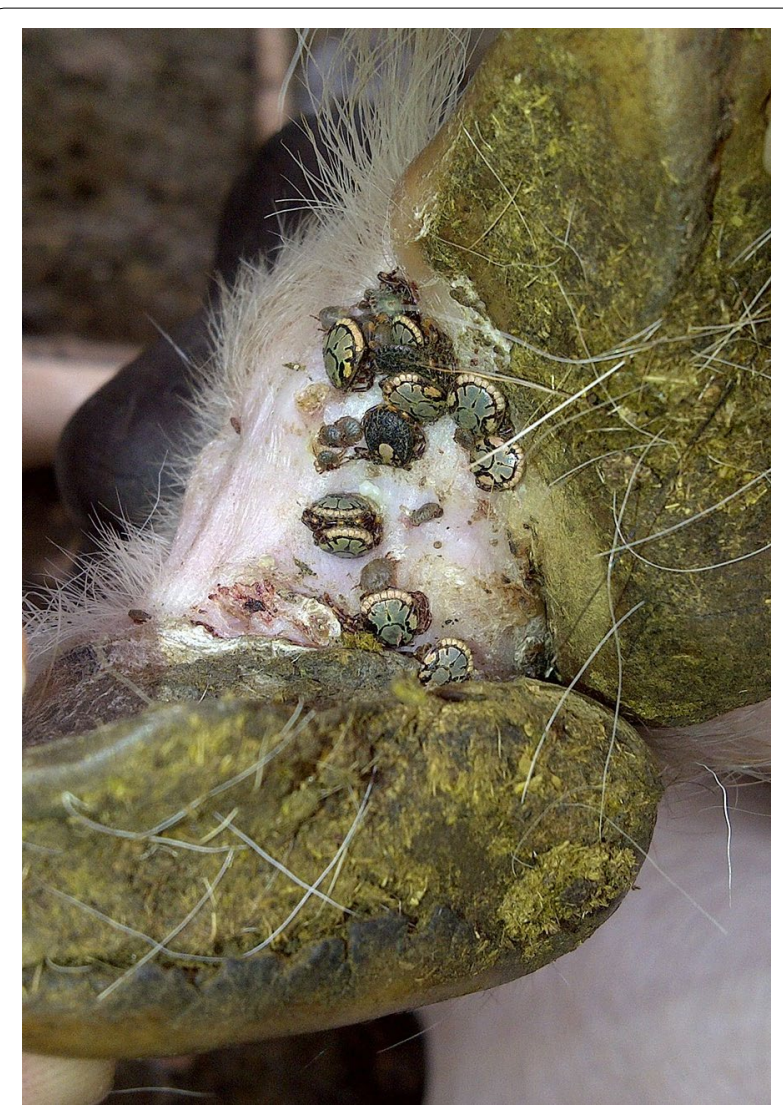

Fig. 2 Infestation with adult Amblyomma hebraeum ticks in the interdigital space of the feet of an indigenous goat in the Mnisi Community Area

Table 5 Mean number of Amblyomma hebraeum ticks per goat collected in each sampling period

\begin{tabular}{llll}
\hline Period & \multicolumn{2}{l}{ Amblyomma hebraeum } & Ratio adult:nymph \\
\cline { 2 - 3 } & Adults & Nymphs & \\
\hline July 2013 & 0.2 & 10.8 & $1: 55.1$ \\
November 2013 & 2.8 & 7.8 & $1: 2.7$ \\
March 2014 & 1.3 & 7.5 & $1: 5.8$ \\
July 2014 & 0.7 & 19.7 & $1: 27.6$ \\
\hline
\end{tabular}

Notes: A highly significant $(P<0.01)$ difference of $A$. hebraeum adults per goat was found between July 2013 and November $2013\left(U_{(93)}=3, Z=4.93424, P<\right.$ 0.00001); between November 2013 and March $2014\left(U_{(93)}=69.5, Z=2.73941\right.$, $P=0.00614)$; between November 2013 and July $2014\left(U_{(86)}=30, Z=3.91612\right.$, $P=0.00008) ;$ and between July 2013 and March $2014\left(U_{(87)}=36, Z=-3.7199\right.$, $P=0.0002)$. A highly significant $(P<0.01)$ difference of $A$. hebraeum nymphs per goat was found between November 2013 and July $2014\left(U_{(86)}=32.5, Z=\right.$ $-3.82986, P=0.00012)$ as well as between March 2014 and July $2014\left(U_{(81)}=28\right.$, $Z=-3.87236, P=0.0001)$

all stages of development can often be found on hosts throughout the year [20]. In the warm, moist, lowveld regions of Mpumalanga Province, the life-cycle seems to be continuous, with little indication of a definite seasonal pattern of abundance for the various life stages.
A previous study conducted in Mpumalanga Province between 1991 and 1993, wherein ticks were collected from indigenous goats owned by small-scale farmers, confirmed that $A$. hebraeum was the most common species, followed by R. appendiculatus and R. evertsi [21]. A slightly different situation with respect to species composition on domestic goats was reported from Zimbabwe, where $R$. evertsi was the predominant species [22]. From the neighbouring Maputo province in Mozambique, a similar species composition has been reported, with $A$. hebraeum, $R$. appendiculatus, $R$. microplus, $R$. evertsi and R. simus [11].

The finding of $R$. microplus on goats is in agreement with records reported in earlier studies [16]. Nyangiwe \& Horak [15] concluded that $R$. microplus, which was considered to be a cattle tick, is in the process of adapting to goats. This implies that these ticks successfully completed their life-cycle on the goats and could even do this in the absence of infested cattle [15]. Therefore, although domestic cattle are the most efficient hosts of $R$. microplus, goats also play a significant role as host. Since only $R$. microplus was recovered from the goats, and $R$. decoloratus was not found, this may suggest that $R$. microplus has displaced $R$. decoloratus, which is in accordance with previous studies $[16,23]$. However, $R$. decoloratus is also a cattle tick as $R$. microplus, and not finding $R$. decoloratus on goats does not prove displacement.

Tønnesen et al. [23] and Horak et al. [11] discussed several reasons for the displacement of $R$. decoloratus by $R$. microplus. One of the reasons was that $R$. microplus males mate with female $R$. decoloratus, leading to the production of sterile offspring [23, 24]. An additional range expansion of $R$. microplus has more recently been reported in South Africa, where the tick is now present throughout the coastal region of the Eastern Cape Province and at multiple localities of the Western Cape Province [25]. Interestingly, however, $R$. microplus has not replaced the indigenous species $R$. decoloratus at all localities for reasons to be further investigated [26].

The mean prevalence of infection for E. ruminantium by PCR/RLB in adult ticks was $17.4 \%$, while $28.4 \%$ of the pooled nymphs were infected. The relatively high prevalence in nymphs was probably due to pooling of nymphs into groups of 10 , which increased the chances of detecting E. ruminantium. The prevalence of E. ruminantium in adult $A$. hebraeum collected from goats in the Mnisi area falls within the same prevalence range recorded in A. hebraeum in other studies conducted in South Africa and Zimbabwe [27, 28]. More recently, however, a much higher E. ruminantium prevalence of $68 \%$ in A. hebraeum ticks collected from goats in four different provinces, including Mpumalanga, was reported [29]. Moreover, E. ruminantium has been detected in blood samples 


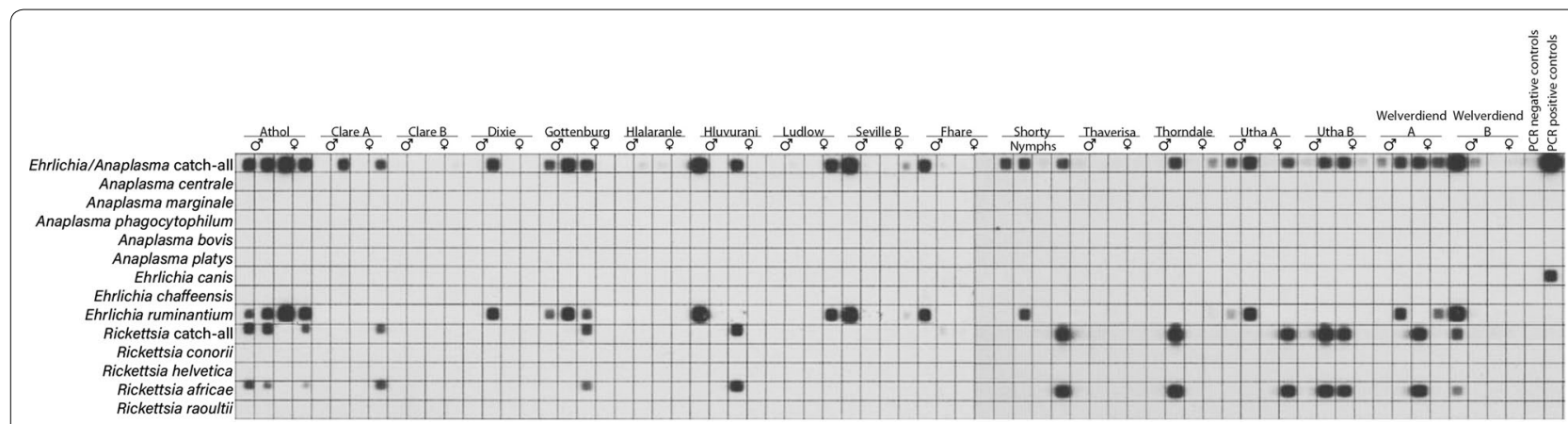

Fig. 3 Reverse line blot hybridisation on adult Amblyomma hebraeum ticks collected in November 2013 from goats in the Mnisi Community Area

Ehrlichia/Anaplasma catch-all

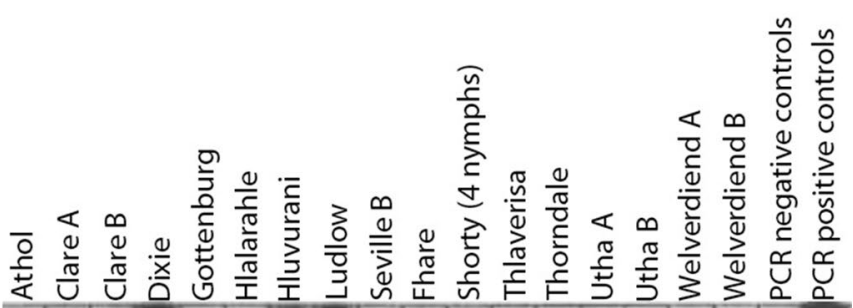

Anaplasma centrale

Anaplasma marginale

Anaplasma phagocytophilum

Anaplasma bovis

Anaplasma platys

Ehrlichia canis

Ehrlichia chaffeensis

Ehrlichia ruminantium

Rickettsia catch-all

Rickettsia conorii

Rickettsia helvetica

Rickettsia africae

Rickettsia raoultii

Fig. 4 Reverse line blot hybridisation on nymphal Amblyomma hebraeum ticks collected in November 2013 from goats in the Mnisi Community Area

Table 6 Co-infection of Ehrlichia ruminantium and Rickettsia africae in adults and nymphal Amblyomma hebraeum ticks

\begin{tabular}{|c|c|c|c|c|c|c|c|c|}
\hline \multirow[t]{2}{*}{ Sampling period } & \multicolumn{4}{|l|}{ Adults } & \multicolumn{4}{|l|}{ Nymphs } \\
\hline & No. tested & ER (\%) & RA (\%) & $\mathrm{Cl}(\%)$ & $\begin{array}{l}\text { No. tested } \\
\text { pools }\end{array}$ & ER (\%) & RA (\%) & $\mathrm{Cl}(\%)$ \\
\hline July 2013 & 23 & $3(13.0)$ & $1(4.3)$ & $1(4.3)$ & 17 & $2(11.8)$ & $3(17.6)$ & 0 \\
\hline November 2013 & 68 & $17(25.0)$ & 16 (23.5) & $5(7.3)$ & 17 & $4(23.5)$ & $5(29.4)$ & 0 \\
\hline March 2014 & 51 & $5(9.8)$ & $5(9.8)$ & 0 & 17 & $7(41.2)$ & $10(58.8)$ & $6(35.9)$ \\
\hline July 2014 & 36 & $6(16.7)$ & $6(16.7)$ & $1(2.8)$ & 16 & $6(37.5)$ & $8(50.0)$ & $4(25.0)$ \\
\hline Total & 178 & $31(17.4)$ & $28(15.7)$ & $7(3.9)$ & 67 & 19 (28.4) & $26(38.8)$ & $10(14.9)$ \\
\hline
\end{tabular}

Abbreviations: ER, Ehrlichia ruminantium; RA, Rickettsia africae; $\mathrm{Cl}$, co-infection 
collected from goats in KwaZulu-Natal and the Free State provinces, with an infection prevalence of $16.4 \%$ and $4.2 \%$, respectively [30].

In the Mnisi area, clinical cases of heartwater have been suspected for some time in goats which died after walking in a circle, paddling with their legs and with a protrusion of the neck. This is most likely due to E. ruminantium infection in the brain, which requires confirmation by the detection of rickettsial inclusion bodies in endothelial cells of capillaries in the brain. If confirmed, it also indicates that indigenous goat breeds are more susceptible to heartwater than suggested [4]. Certain breeds of goats are more resistant than others, making the introduction of high-producing animals into rural Amblyomma areas difficult [21]. Moreover, trade and movement of livestock across geographical regions jeopardise the establishment of a robust immunity against heartwater, for instance in restocking exercises in Mozambique [31].

Rickettsia africae infections were also detected in adult Amblyomma ticks (15.7\%), whereas nearly $40 \%$ of pooled nymphal samples carried this infection. Co-infections of $E$. ruminantium and $R$. africae in adults and nymphal tick pools occurred in 3.9\% (7/178) and 14.9\% (10/67), respectively. African tick-bite fever has been detected in Amblyomma ticks and in patients in at least 14 African countries, with up to $11 \%$ of infections being acquired by international travellers returning from South Africa [6]. Although exposure of the local community in the Mnisi area to infected ticks must be substantially higher, human cases have not been reported. Elsewhere, for instance in Madagascar, high infection rates of R. africae in A. variegatum have been correlated with a low prevalence of anti-rickettsial antibodies in healthy pregnant women [32]. A systematic one-health approach encompassing the entire ecosystem, wherein humans, livestock, wildlife and (ecto)-parasites co-exist, is currently underway and is expected to answer the many questions that go beyond the scope of the limited investigation reported here.

Lameness due to predilection of ticks for the interdigital space of feet was observed in $89 \%$ of the households. The occurrence of foot abscesses in goats has been linked to the seasonal abundance of adult $A$. hebraeum and R. glabroscutatum [14]. Another tick that is notorious with respect to foot infestations and temporary lameness is Hyalomma rufipes, in particular on Merino sheep in the Free State of South Africa [33]. Despite the importance of goats for the livelihoods of farmers in the area, tick control is not practiced on any systematic scale. At a recent farmer's day, clear interest was expressed by the owners for improved animal health management through tick control on their goats, leading to enhanced livelihoods. As a result, and after consultation with the local authorities and farmers' associations, several interventions were carried out with the aim of reducing the negative impact of ticks on the health of indigenous goats. Since A. hebraeum prefers hairless areas in the lower perennial region, at the axillae, genitalia, on the udder and under the tail of cattle, as well as attaching to the inter-digital space of goats and sheep, control may be more effective by targeted application of acaricides. Interventions carried out thus far include weekly treatment of predilection sites with deltamethrin, formulated as a tick grease, and three-weekly topical applications of a combination of amitraz with deltamethrin for the control of ticks on goats. In general, these interventions have successfully reduced tick burdens, but as soon as they were withheld, infestation levels were back to levels prior to treatment (Jongejan et al., unpublished results). Therefore, acaricide-impregnated collars with high and sustained efficacy against ticks on dogs and cats could be considered. However, due to their browsing behaviour, goats may risk losing these collars. Instead, a leg-band close to the proximity where ticks enter the host and close to their predilection site may be a more sustainable solution. This could dramatically improve the health and wellbeing of the indigenous goat population in the Mnisi area. If successful, this type of control could be applied in a much wider area throughout subSaharan Africa, where goats are kept under communal grazing conditions in pastures infested by Amblyomma ticks.

\section{Conclusions}

Amblyomma hebraeum was the predominant tick species on goats in the Mnisi Community area and was infected with $E$. ruminantium and $R$. africae. Moreover, $R$. microplus appeared to be adapted to feed on goats in this area of South Africa. The use of acaricide-impregnated leg-bands is recommended as a sustainable tick control method on goats to kill ticks and reduce lameness. This intervention is probably the most effective one during the summer period at the peak of the adult tick infestation. Finally, the observation that goats are continuously challenged by substantial numbers of E. ruminantiuminfected $A$. hebraeum ticks throughout the year is a major obstacle preventing the upgrade of local goat breeds. Humans may be at risk of contracting tick-bite fever in this area.

\section{Abbreviations}

RLB: reverse line blot; SDS: sodium dodecyl sulfate; PCR: polymerase chain reaction; streptavidine-POD: streptavidine-peroxidase; SSPE: sodium chloridesodium phosphate-EDTA. 


\section{Acknowledgements}

We are very grateful for the continued cooperation of the farmers' community and the support provided by the environmental monitors of the Mnisi Community Program. This research was conducted in the context of a memorandum of understanding between the Faculty of Veterinary Medicine of Utrecht University and the Faculty of Veterinary Science of the University of Pretoria. Publication of this paper has been sponsored by Bayer Animal Health in the framework of the 15th Companion Animal Vector-borne Diseases (CVBD) World Forum Symposium.

\section{Authors' contributions}

FJ and HS conceptualised the study. FS, ID, BS and TL conducted the field work consisting of tick collection and identification as well as holding questionnaires with the owners. SB conducted and coordinated the field collections. $\mathrm{LB}$ and SB conducted the PCR/RLB tests. BS analysed the data and added the statistics. JW and LB coordinated the laboratory work at the Hans Hoheisen Research Centre and at the Utrecht Centre for Tick-borne diseases, respectively. FJ wrote the paper, and the co-authors made various contributions and gave their consent to the final version. All authors read and approved the final manuscript.

\section{Funding}

This research was supported by the Faculty of Veterinary Medicine of Utrecht University and the Faculty of Veterinary Science of the University of Pretoria.

\section{Availability of data and materials}

Data supporting the conclusions of this article are included within the article. The dataset used in this study and the extracted DNA from the collected ticks are available upon reasonable request.

\section{Ethics approval and consent to participate}

Section 20 and ethical approval was granted for this study. Removal of ticks was done according to approved World Organization for Animal Health (OIE) international standards and was carried out with the consent of the goat owners.

\section{Consent for publication}

Not applicable.

\section{Competing interests}

The authors declare that they have no competing interests.

\section{Author details}

${ }^{1}$ Vectors and Vector-borne Diseases Research Programme, Department of Veterinary Tropical Diseases, Faculty of Veterinary Science, University of Pretoria, Private Bag X04, Onderstepoort 0110, Republic of South Africa. ${ }^{2}$ Utrecht Centre for Tick-borne Diseases (UCTD), FAO Reference Centre for Ticks and Tick-borne Diseases, Faculty of Veterinary Medicine, Utrecht University, Yalelaan 1, $3584 \mathrm{CL}$ Utrecht, The Netherlands. ${ }^{3}$ Present Address: Small Animal Hospital, Royal (Dick) School of Veterinary Studies, University of Edinburgh, Easter Bush Campus, Edinburgh EH25 9RG, UK. ${ }^{4}$ Present Address: Cape Cross Veterinary Hospital, 8 Jacaranda Street, Wavecrest, Jeffrey's Bay 6330, Republic of South Africa. ${ }^{5}$ Hans Hoheisen Research Platform, Center for Veterinary Wildlife Studies, Faculty of Veterinary Science, University of Pretoria, Hans Hoheisen Wildlife Research Station, Orpen, Mpumalanga, Republic of South Africa.

Received: 8 December 2019 Accepted: 1 April 2020

Published online: 21 April 2020

\section{References}

1. Jongejan F, Uilenberg G. The global importance of ticks. Parasitology. 2004;129:S3-14.

2. Beugnet F, Marié J-L. Emerging arthropod-borne diseases of companion animals in Europe. Vet Parasitol. 2009;163:298-305.

3. de la Fuente J, Estrada-Pena A, Venzal JM, Kocan KM, Sonenshine DE. Overview: ticks as vectors of pathogens that cause disease in humans and animals. Front Biosci. 2008;13:6938.
4. Yunker CE. Heartwater in sheep and goats: a review. Onderstepoort J Vet Res. 1996;63:159-70.

5. Kelly PJ, Beati L, Mason PR, Matthewman LA, Roux V, Raoult D. Rickettsia africae sp. nov., the etiological agent of African tick bite fever. Int J Syst Bacteriol. 1996:46:611-4.

6. Althaus F, Greub G, Raoult D, Genton B. African tick-bite fever: a new entity in the differential diagnosis of multiple eschars in travelers. Description of five cases imported from South Africa to Switzerland. Int J Infect Dis. 2010;14:e274-6.

7. Mack I, Ritz N. African tick-bite fever. N Engl J Med. 2019;380:960.

8. Bogovic P, Lotric-Furlan S, Korva M, Avsic-Zupanc T. African tick-bite fever in traveler returning to Slovenia from Uganda. Emerg Infect Dis. 2016:22:1848-9.

9. Rumosa Gwaze F, Chimonyo M, Dzama K. Estimation of goat production potential and efficiency in the resource-poor communal areas of the Eastern Cape Province of South Africa. Trop Anim Health Prod. 2010;42:1235-42.

10. Slayi M, Maphosa V, Fayemi OP, Mapfumo L. Farmers' perceptions of goat kid mortality under communal farming in Eastern Cape, South Africa. Trop Anim Health Prod. 2014:46:1209-15.

11. Horak IG, Nyangiwe N, De Matos C, Neves L. Species composition and geographic distribution of ticks infesting cattle, goats and dogs in a temperate and in a subtropical region of south-east Africa. Onderstepoort J Vet Res. 2009;76:263-76.

12. Petney TN, Horak IG, Rechav Y. The ecology of the African vectors of heartwater, with particular reference to Amblyomma hebraeum and Amblyomma variegatum. Onderstepoort J Vet Res. 1987:54:381-95.

13. McCrindle CME, Maime MJ, Botha EA, Webb EC, Smuts MP. Scrotal tick damage as a cause of infertility in communal bulls in Moretele, South Africa. J S Afr Vet Assoc. 2019;90:1966.

14. Maclvor KM, Horak IG. Foot abscess in goats in relation to the seasonal abundance of adult Amblyomma hebraeum and adult Rhipicephalus glabroscutatum (Acari: Ixodidae). J S Afr Vet Assoc. 1987:58:113-8.

15. Nyangiwe N, Horak IG. Goats as alternative hosts of cattle ticks. Onderstepoort J Vet Res. 2007;74:1-7.

16. Nyangiwe N, Harrison A, Horak IG. Displacement of Rhipicephalus decoloratus by Rhipicephalus microplus (Acari: Ixodidae) in the Eastern Cape Province, South Africa. Exp Appl Acarol. 2013;61:371-82.

17. Bekker CPJ, De Vos S, Taoufik A, Sparagano OAE, Jongejan F. Simultaneous detection of Anaplasma and Ehrlichia species in ruminants and detection of Ehrlichia ruminantium in Amblyomma variegatum ticks by reverse line blot hybridization. Vet Microbiol. 2002:89:223-38.

18. Olivieri E, Wijnveld M, Bonga M, Berger L, Manfredi MT, Veronesi F, et al. Transmission of Rickettsia raoultii and Rickettsia massiliae DNA by Dermacentor reticulatus and Rhipicephalus sanguineus (s.l.) ticks during artificial feeding. Parasit Vectors. 2018:11:494.

19. Jongejan F, de Jong S, Voskuilen T, van den Heuvel L, Bouman R, Heesen $\mathrm{H}$, et al. "Tekenscanner": a novel smartphone application for companion animal owners and veterinarians to engage in tick and tick-borne pathogen surveillance in the Netherlands. Parasit Vectors. 2019;12:116.

20. Horak IG, Maclvor KM, Petney TN, De Vos V. Some avian and mammalian hosts of Amblyomma hebraeum and Amblyomma marmoreum (Acari: Ixodidae). Onderstepoort J Vet Res. 1987:54:397-403.

21. Bryson NR, Tice GA, Horak IG, Stewart CG, du Plessis BJA. Ixodid ticks on indigenous goats owned by small-scale farmers in four communal grazing areas in South Africa. J S Afr Vet Assoc. 2002;73:26-30.

22. Hove T, Mukandi R, Bere M, Horak IG, Latif AA. Ixodid ticks infesting domestic goats in communal land areas of Zimbabwe. J S Afr Vet Assoc. 2008;79:116-20.

23. Tønnesen MH, Penzhorn BL, Bryson NR, Stoltsz WH, Masibigiri T. Displacement of Boophilus decoloratus by Boophilus microplus in the Soutpansberg region, Limpopo Province, South Africa. Exp Appl Acarol. 2004;32:199-208.

24. Horak IG, Fourie LJ, Novellie PA, Williams EJ. Parasites of domestic and wild animals in South Africa. XXVI. The mosaic of ixodid tick infestations on birds and mammals in the Mountain Zebra National Park. Onderstepoort J Vet Res. 1991;58:125-36.

25. Nyangiwe N, Horak IG, Van der Mescht L, Matthee S. Range expansion of the economically important Asiatic blue tick, Rhipicephalus microplus, in South Africa. J S Afr Vet Assoc. 2017;88:1482. 
26. Yawa M, Nyangiwe N, Kadzere CT, Muchenje V, Mpendulo T, Marufu MC. In search of the Rhipicephalus (Boophilus) microplus in the western-central regions of the Eastern Cape Province, South Africa. Ticks Tick Borne Dis. 2019;10:564-7.

27. Bryson NR, Horak IG, Venter EH, Mahan SM, Simbi B, Peter TF. The prevalence of Cowdria ruminantium in free-living adult Amblyomma hebraeum collected at a communal grazing area and in 2 wildlife reserves in South Africa. J S Afr Vet Assoc. 2002;73:131-2.

28. Norval RA, Andrew HR, Yunker CE. Infection rates with Cowdria ruminantium of nymphs and adults of the bont tick Amblyomma hebraeum collected in the field in Zimbabwe. Vet Parasitol. 1990;36:277-83.

29. Mtshali K, Khumalo Z, Nakao R, Grab DJ, Sugimoto C, Thekisoe O. Molecular detection of zoonotic tick-borne pathogens from ticks collected from ruminants in four South African provinces. J Vet Med Sci. 2015;77:1573-9.

30. Ringo AE, Adjou Moumouni PF, Taioe M, Jirapattharasate C, Liu M, Wang $\mathrm{G}$, et al. Molecular analysis of tick-borne protozoan and rickettsial pathogens in small ruminants from two South African provinces. Parasitol Int. 2018;67:144-9.
31. Bekker CPJ, Vink D, Pereira CML, Wapenaar W, Langa A, Jongejan F. Heartwater (Cowdria ruminantium infection) as a cause of postrestocking mortality of goats in Mozambique. Clin Diagn Lab Immunol. 2001;8:843-6.

32. Keller C, Krüger A, Schwarz NG, Rakotozandrindrainy R, Rakotondrainiarivelo JP, Razafindrabe T, et al. High detection rate of Rickettsia africae in Amblyomma variegatum but low prevalence of anti-rickettsial antibodies in healthy pregnant women in Madagascar. Ticks Tick Borne Dis. 2016;7:60-5.

33. Kok DJ, Fourie $L J$. The role of Hyalomma ticks in foot infestations and temporary lameness of sheep in a semi-arid region of South Africa. Onderstepoort J Vet Res. 1995;62:201-6.

\section{Publisher's Note}

Springer Nature remains neutral with regard to jurisdictional claims in published maps and institutional affiliations.
Ready to submit your research? Choose BMC and benefit from:

- fast, convenient online submission

- thorough peer review by experienced researchers in your field

- rapid publication on acceptance

- support for research data, including large and complex data types

- gold Open Access which fosters wider collaboration and increased citations

- maximum visibility for your research: over $100 \mathrm{M}$ website views per year

At BMC, research is always in progress.

Learn more biomedcentral.com/submissions 